\title{
Integrating invasive mammal eradications and biodiversity offsets for fisheries bycatch: conservation opportunities and challenges for seabirds and sea turtles
}

\author{
C. Josh Donlan · Chris Wilcox
}

Received: 8 October 2007/ Accepted: 15 October 2007 / Published online: 31 October 2007

(C) Springer Science+Business Media B.V. 2007

\begin{abstract}
The removal of invasive mammals from islands is one of society's most powerful tools for preventing extinctions and restoring ecosystems. Given the demonstrable high conservation impact and return on investment of eradications, new networks are needed to fully leverage invasive mammal eradications programs for biodiversity conservation at-large. There have been over 800 invasive mammal eradications from islands, and emerging innovations in technology and techniques suggest that island area will soon no longer be the limiting factor for removing invasive mammals from islands. Rather, securing the necessary social and economic capital will be one main challenge as practitioners target larger and more biologically complex islands. With a new alliance between conservation practitioners and the fisheries sector, biodiversity offsets may be a promising source of capital. A suite of incentives exists for fisheries, NGOs, and governments to embrace a framework that includes fishery bycatch
\end{abstract}

C. J. Donlan $(\bowtie)$

Advanced Conservation Strategies, P.O. Box 8254,

Santa Cruz, CA, USA

e-mail: jdonlan@advancedconservation.org

C. J. Donlan

Department of Ecology and Evolutionary Biology,

Cornell University, Corson Hall, Ithaca, NY 14853, USA

C. Wilcox

CSIRO Marine and Atmospheric Research,

Hobart 7001, TAS, Australia offsets for seabirds and sea turtles. A bycatch management framework based on the hierarchy of "avoid, minimize, and offset" from the Convention on Biological Diversity would result in cost-effective conservation gains for many threatened seabirds and sea turtles affected by fisheries. Those involved with island conservation and fisheries management are presented with unprecedented opportunities and challenges to operationalize a scheme that will allow for the verifiable offset of fisheries impacts to seabirds and sea turtles, which would likely result in unparalleled marine conservation gains and novel cross-sector alliances.

Keywords Invasive mammal eradication . Biodiversity offsets - Fisheries bycatch . Cost-effective conservation $\cdot$ Seabirds .

Sea turtles

Anyone who has visited an island before and after rats have been removed has likely witnessed firsthand the conservation power of eradication. Tremendous progress has been made over the past two decades in terms of our ability to eradicate invasive mammals from islands (Towns and Broome 2003; Veitch and Clout 2002). About 25 years ago, New Zealand conservationists were struggling to eradicate rats (Rattus spp.) from islands the size of a football field (Thomas and Taylor 2002). In 2002, they did so on an island the size of 16,000 football fields 
(11,300 ha), and the Campbell Island eradication campaign was run so efficiently that it serves as a case study for innovation in the public service (McClelland and Tyree 2002; Wright and Joux 2003). Halfway around the world, other eradications are taking place that were deemed impossible a decade ago. The Galápagos National Park and the Charles Darwin Foundation recently eradicated goats (Capra hircus) from the two of the largest islands in the Galapagos archipelago: Santiago (58,465 ha) and Isabela Island (458,812 ha). Those interventions were swifter and more cost-effective than ever before: over 160,000 goats were removed from the two islands in less than 5 years for $\sim \$ 18$ per hectare (US $\$ 2006$ dollars; Cruz et al. unpublished data). Others have developed techniques to successful mitigate for nontarget impacts from rodenticide applications during eradications, which has facilitated successful invasive rat removals on two islands where native small mammals are present that were equally susceptible to the rodenticide (Howald et al. 2007). From many perspectives, the bar for invasive mammal eradications has been raised by magnitudes.

Now more than ever, the removal of invasive mammals from islands is one of society's most powerful tools for preventing extinctions and restoring ecosystems. Accumulating pre-eradication impact and post-eradication recovery studies now support the alleged biodiversity benefits of eradication. (Croll et al. 2005; Donlan et al. 2002; Fukami et al. 2006; Nogales et al. 2004; Towns et al. 2006; Wanless et al. 2007; Whitworth et al. 2005). This is particularly the case for seabirds, which invasive species are the primary threat followed by fisheries interactions and habitat loss (Buckelew 2007). For example, feral cat eradication decreased Black-vented shearwater (Puffinus opisthomelas) mortality by $90 \%$, and experimental black rat control programs on Cory's Shearwater (Calonectris diomedea) colonies decreased chick mortality by over $50 \%$ (Igual et al. 2006; Keitt and Tershy 2003). These documented benefits in Mexico and Spain are becoming commonplace and cosmopolitan, yet outside of New Zealand and Australia, eradication arguably remains in the shadows of biodiversity conservation practice (Donlan et al. 2003; Simberloff 2001).

Policy makers and on-the-ground practitioners are uninformed of the current technology and techniques available to tackle this biodiversity threat. Few are aware that rats have been removed from an island the size of Washington DC and goats from an island the size of Rhode Island. At the same time, awareness of the impacts of invasive species has exploded over the past decade, creating significant research programs and opportunities (e.g., the US government spent $\$ 635$ million on invasive species in 2000). Yet, relatively few resources have been invested in actively removing invasive mammals from islands. Nonetheless, there have been over 800 invasive vertebrate eradications from islands, with larger and larger islands being targeted (Fig. 1). Recent successes indicate that island size may no longer be limiting for the eradication of species such as goats and Norway rats (Rattus norvegicus, Campbell and Donlan 2005; Howald et al. 2007). However, island size still appears to be a factor limiting the removal of other invasive mammals such as house mice (Mus musculus). Nonetheless, emerging innovations in eradication technology and techniques (Burbidge 2004; Lavoie et al. 2007; Parkes et al. 2005) suggest that island area will soon no longer be the limiting factor for invasive mammal eradications (Table 1). On that assumption, island conservation will face three main challenges as practitioners target larger and more biological complex islands often with human inhabitants: (1) mitigating for non-target impacts; (2) increasing the cost-effectiveness of eradication campaigns; and (3) securing the necessary social and economic capital. In this essay, we discuss one idea regarding the latter.

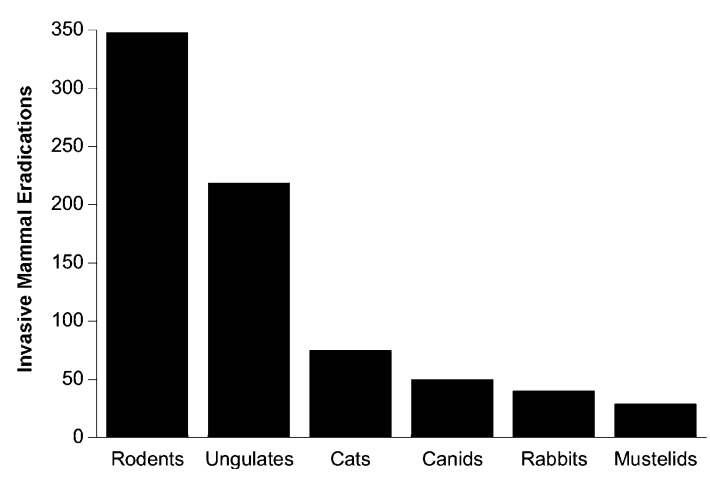

Fig. 1 Number of successful invasive mammal eradications on islands worldwide for rodents, ungulates, cats, pigs, and rabbits. References: Nogales et al 2004; Campbell and Donlan 2005; Howald et al. 2007; Campbell, personal communication; Keitt, personal communication 
Table 1 Innovation over the past two decades in the ability to remove invasive mammals from larger and larger islands

\begin{tabular}{|c|c|c|c|}
\hline Target Species & $1990 \mathrm{~s}$ & $2000 \mathrm{~s}$ & Planned \\
\hline House mice (Mus musculus) & 710 Enderby, New Zealand & 219 Fřgate, Seychelles & $\begin{array}{l}\text { 12,800 Macquarie, } \\
\text { Australia }\end{array}$ \\
\hline Kiore (Rattus exulans) & 1,965 Kapiti, New Zealand & 3,083 Little Barrier, New Zealand & \\
\hline Black rats (Rattus rattus) & 800 St. Paul, France & 1,022 Hermite, Australia & $\begin{array}{l}\text { 12,800 Macquarie, } \\
\text { Australia }\end{array}$ \\
\hline Norway rats (Rattus norvegicus) & 3,105 Langara, Canada & 11,300 Campbell, New Zealand & 27,800 Kiska, USA \\
\hline Cats (Felis catus) & 29,000 Marion, South Africa & 12,800 Macquarie, Australia & $\begin{array}{l}\text { 58,640 Dirk Hartog, } \\
\text { Australia }\end{array}$ \\
\hline Rabbits (Oryctolagus cuniculus) & 1,421 Deserta Grande, Portugal & 3,450 Norfolk, Australia & $\begin{array}{l}\text { 12,800 Macquarie, } \\
\text { Australia }\end{array}$ \\
\hline Goats (Capra hircus) & 21,853 Santa Rosa, USA & 458,812 Isabela, Ecuador & $\begin{array}{l}\text { 171,617 Galapagos } \\
\text { archipelago (in progress) }\end{array}$ \\
\hline Pigs (Sus scrofa) & 21,118 Santa Catalina, USA & 58,465 Santiago, Ecuador & $\begin{array}{l}\text { 45,975 Auckland, } \\
\text { New Zealand }\end{array}$ \\
\hline
\end{tabular}

The largest islands (size in hectares) where invasive mammals were successfully removed during the 1990s, 2000s, and currently planned

References: Nogales et al. 2004; Campbell and Donlan 2005; Howald et al. 2007; Springer, personal communication; Campbell, personal communication; Howald, personal communication

Biodiversity offsets may be a promising source for funding systematic and large-scale invasive mammal eradication programs. Biodiversity offsets can be defined as 'conservation actions intended to compensate for the residual, unavoidable harm to biodiversity caused by development projects, so as to ensure no net loss of biodiversity' (ten Kate et al. 2004, p. 13). Many in the business sector have begun to adopt a no net loss framework under an avoid, mitigate, offset hierarchy that flows from the Convention on Biological Diversity (Slootweg et al. 2006; ten Kate et al. 2004). Under this framework, we propose that the fisheries sector could benefit from being strategically and tactically linked to island conservation and vice versa. This potential partnership could facilitate invasive mammal eradications playing a larger, more integrated role in biodiversity conservation, and allow fisheries to minimize their environmental impacts while still making a profit. In fact, we argue that such a partnership is a prerequisite for most fishing enterprises to be impact neutral or positive with respect to seabird or sea turtle bycatch. The proposed alliance and its conservation potential hinges on two observations. First, many of the threatened seabird and sea turtle species affected by fisheries are the biodiversity targets of island conservation practitioners. Second, fisheries management is complex, expensive, and intrinsically involves trade-offs; in contrast, conservation interventions on islands are often cost-effective, high-impact, and relatively straightforward with low opportunity costs.

\section{Fisheries and island conservation: a new alliance?}

The social and economic importance of fisheries and the biological realities of overfishing and bycatch result in major tensions over ocean resources. Globally, fisheries provide over a tenth of all protein consumed by humans, employ hundreds of millions of people, and are valued at $\sim$ US $\$ 80$ billion (Botsford et al. 1997; FAO 2004). Yet, at least a quarter of the global catch is non-target species and discarded (Alverson et al. 1994). That mortality is having major impacts on species and ecosystems (Hall et al. 2000; Lewison et al. 2004). For many fisheries, much of that discarded bycatch is endangered seabirds and sea turtles-species that spend part of their life breeding on islands and coastal beaches. At those breeding sites, seabirds and sea turtles commonly face additional anthropogenic mortality impacts, such as coastal development, direct human take, and impacts from invasive predators (Caut et al. in press; Engeman et al. 2006; Jones et al. in press). Indeed most seabirds and sea turtles that are threatened by fisheries interactions are concurrently threatened by 
additional anthropogenic threats (Koch et al. 2005; Mast 2005; Wilcox and Donlan 2007, Fig. 2).

Fisheries are increasingly under national and international pressures to operate more responsibly. Further, many states are moving toward a costrecovery model in fisheries management, where the industry pays for the costs related to its activities (Cox 2000). Those statutory and social pressures include demands to minimize bycatch. Encouragingly, changing in fishing practices and technological innovations have spurred reductions of seabird and sea turtle bycatch (Gilman et al. 2005, 2006). Many are adopting those measures, such as the Commission for the Conservation of Antarctic Marine Living Resources (CCAMLR), which is the regional fisheries management organization for the southern oceans. Their effort to reduce bycatch is unprecedented, which includes bycatch data collection, observer and research programs, and mitigation requirements such as streamer poles and weighted lines (Small 2005). Those efforts have produced impressive results: longline seabird mortality in the majority of the convention area was reduced from 6,589 birds in 1997 to 15 birds in 2003 (excluding Economic Exclusive Zones (EEZ), CCAMLR 2003; Small 2005).

Unfortunately, those incidental mortality rates pale in comparison to other regional fisheries management organizations, whose bycatch rates remain largely unknown due to lack of data collection and transparency (Small 2005). Japanese long-line vessels alone are estimated to kill 6,000-9,000 birds per year in the area managed by the Commission for the Conservation of Southern Bluefin Tuna (Kiyota and Takeuchi 2004 cited in Small 2005). But even in the most responsibly managed fisheries such as CCAMLR, seabird and sea turtle bycatch occurs at low levels. Depending on the species, the death of $9,000,15$, or even a single individual can have significant population-level consequences.

Encouraging fisheries to offset bycatch that cannot be mitigated directly (either by avoidance or modifying fishing practices) by funding conservation interventions targeted toward other mortality threats could result in net conservation gains for seabirds and sea turtles (Wilcox and Donlan 2007). Interventions could include invasive predator control on mainland breeding sites, combating IUU fishing (illegal, unregulated, and unflagged), conservation incentive agreements with artesanal fishing communities that are also impacting the species of concern, or invasive mammal eradications on breeding islands. In some cases, the transfer of capital from a impact that is associated with revenue-generating activities to address an impact that is revenue-neutral or -negative would result in cost-effective interventions with high conservation returns, even after discounting demographic delays (i.e., allowing current impacts for future benefits, Wilcox and Donlan 2007).

The idea of linking fisheries bycatch management and invasive mammal eradications will be sure to
Fig. 2 Percent of seabirds listed by the IUCN that are threatened by invasive species and fisheries bycatch, and the percent of seabirds threatened directly by fisheries bycatch that are also threatened by invasive species. Includes all seabirds listed as critical endangered (CR), endangered (EN), vulnerable (VU), and extinct (EX); data from IUCN/Birdlife

International's World Bird Database, $n=104$ )

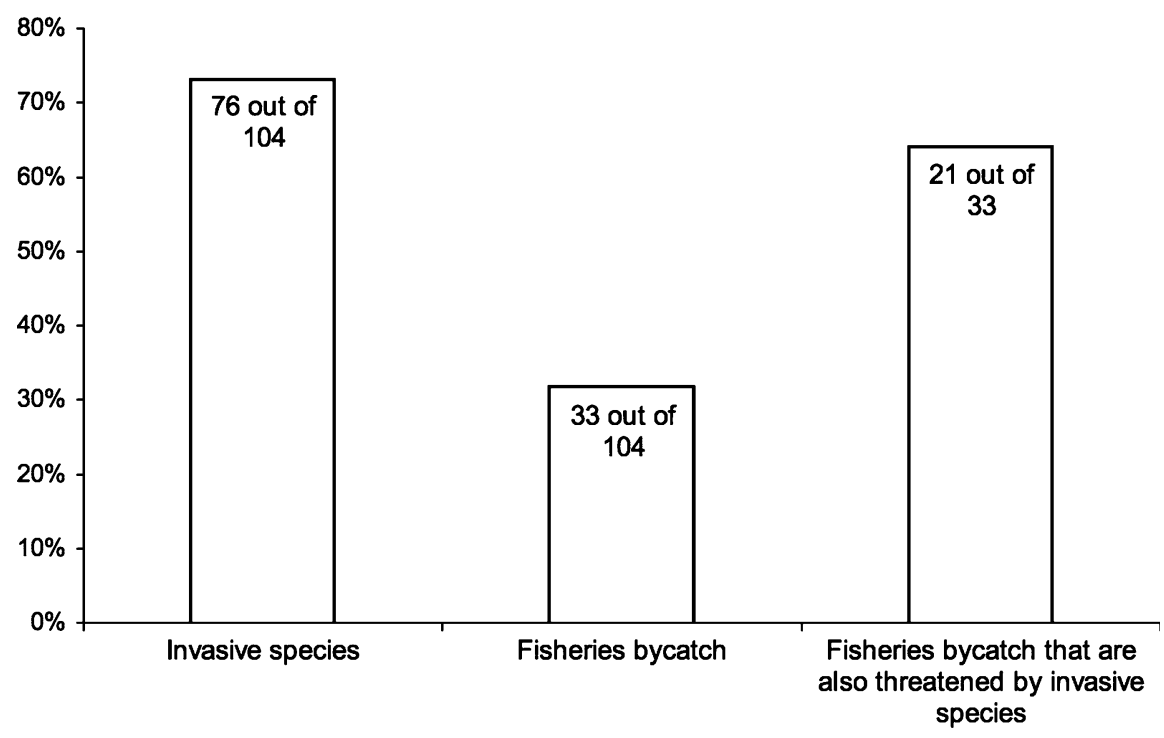


raise many challenges and concerns. We briefly discuss two pivotal questions.

\section{Why should fisheries pay for invasive mammal eradications as part of their bycatch management strategy?}

Fisheries could benefit from incorporating offsets into their bycatch management strategy. Fishers could be motivated since voluntary offsets would likely contribute to a company's social license to operate, regulatory goodwill, and reputation (ten Kate et al. 2004). Offsets could also lower compliance costs, and responsibly transfer liability to account for residual seabird and sea turtle bycatch to a third party with specific expertise (e.g., a conservation NGO, ten Kate et al. 2004). Offsets could also address a growing, underappreciated concern of the seafood industry: reliability of supply. Continuity of supply is needed to establish long-term markets, and with courtimposed fisheries closures due to bycatch becoming commonplace, wholesalers, retailers, and restaurants are faced with the dilemma of permanently discontinuing popular but volatile seafood products (Chambers 2000). Lastly, a net-neutral or -positive seabird/sea turtle bycatch fishing enterprise might be able to increase its market access or gain a premium price for its products. Eco-labeling of seafood products, such as Marine Stewardship Council's Fishery Certification Program, has garnered much interest by fisheries and consumers (Roheim 2003). While there are many challenges to effective awareness consumer campaigns (Jacquet and Pauly 2007), consumer demand and access to certified products is growing in the United States, Europe, Australia, and New Zealand, and certified fisheries are experiencing increase access to those markets (Roheim 2003).

Combined with direct bycatch mitigation programs (e.g., circle hooks, weighted lines, etc), a verifiable offset program would give many fisheries an unprecedented opportunity to have a net positive impact on seabirds and sea turtles. Other sectors have set the precedent with similar thinking: the mining industry is now routinely engaging in dialogues that are moving away from dualistic frameworks (e.g., environmental impact versus jobs and profitability) and toward multidisciplinary, holistic approaches that are grounded in the hierarchy of avoid, mitigate, and offset (Hodge 2004; ten Kate et al. 2004). The fisheries sector has expressed interest in similar approaches. The challenge will rest largely in the hands of the conservation NGOs and governments to engage them.

\section{Why should conservation organizations endorse and management agencies allow or require fisheries to offset bycatch that cannot be avoided and mitigated directly via fishing modifications?}

Fisheries management is expensive endeavor: the European Union, United States, and Japan spent US\$1.7 billion in 1999 on fisheries enforcement, research, and management (OECD 2003). Fisheries management is also increasingly complex, culturally, economically, and environmentally (e.g., Kilgannon 2007). For example, while progress is being made toward the sustainable management of US coastal fisheries (Christensen 2006), many issues and problems are merely exported at a 6:1 ratio: total fisheries imports in 2005 was $\$ 25.1$ billion compared to $\$ 3.9$ billion in US landings (NMFS 2007). Globalization and governance present the major challenges for the sustainable management of our oceans (Crowder et al. 2006), including the conservation of marine apex predators that are affected by fisheries bycatch. Opportunity costs and complex trade-offs abound with fisheries management decisions.

In contrast, there are tens of thousands of islands throughout the world's oceans where the eradication of invasive mammals would be feasible, straightforward, and have low opportunity costs. Unlike the public health sector, biodiversity conservation practitioners are just beginning to incorporate the economic costs of interventions into their planning (Naidoo et al. 2006; Pullin and Knight 2001). While economic data is unavailable for most eradications, recent campaigns suggest that even large-scale eradications are highly cost-effective (Donlan and Wilcox 2007). For example, seabird breeding colonies in northwest Mexico have been protected for the cost of US\$21,615 per colony (Aguirre-Muñoz et al. 2007). For many seabird populations, eradication campaigns at breeding colonies are the 'low-hanging fruit' on the conservation tree. Given that invasive mammals are still present on at least $80 \%$ of the world's islands, money will be a major limiting factor to island 
conservation in the coming decades (Campbell and Donlan 2005; Howald et al. 2007). By engaging fisheries in a dialogue about offsets for seabird and sea turtle bycatch, conservation organizations and governments could generate novel conservation dollars and facilitate cost-effective biodiversity gains. As important, governments could efficiently recover costs from fisheries for services they consume, and seabird and sea turtle conservation could rely less on charity for funding as it turns toward resource users to pay for their impacts on common pool resources (Barnes 2006).

The potential value of biodiversity offsets on fisheries bycatch impacts should rest on the counterfactual: what would have happened if no offset had occurred? Conservationists have yet to fully embrace the measurement of counterfactual outcomes in program evaluations (Ferraro and Pattanayak 2006). The management of the US Hawaiian swordfish fishery provides an insightful and intriguing example.

When the Hawaiian swordfish fleet was ordered to stop fishing under the US Endangered Species Act in 2001 due to incidental bycatch of sea turtles, swordfish landings decreased by $93 \%$ (Sarmiento 2006). However, this enforcement and subsequent closure was restricted solely to the US Hawaiian fleet, and thus other fleets moved into the area compensating for the lost fishing effort, including Panama, Ecuador, and other largely unregulated distant water fishing nations (Sarmiento 2006). Thus, both the counterfactual and conservation outcomes are unclear when the US fleet (worth $\$ 50$ million per year in revenue in 2000) was sent home again in March 2006 after meeting their annual limit of 17 interactions with the threatened loggerhead sea turtle (Caretta caretta, Anonymous 2006). However, given the fishing effort compensation by unregulated fleets documented above, sea turtle mortality could have arguably and ironically increased as a result of the US Hawaiian swordfish fishery closures.

Would a different approach under the avoid, mitigate, and offset framework endorsed by the Convention on Biological Diversity (Slootweg et al. 2006) lead to a better biodiversity outcome? Entertain a scenario that once the fishing fleet reached the annual limit of sea turtle interactions they would remain at-sea fishing and offset their sea turtle interactions by funding conservation interventions that targeted other mortality sources. The offset ratio would be conservative, and encompass a discount rate and demographic uncertainties (e.g., $X^{*} Y$ sea turtles protected or produced for every $X$ sea turtle interaction). Contrary to the idea of letting the fishers 'off the hook', the Hawaiian fleet, whom have already significantly reduced sea turtle bycatch by switching to circle hooks (Gilman et al. 2007), would have additional incentives to avoid sea turtle bycatch with a bycatch levy or similar financial instrument (e.g., Pigovian tax, Wilcox and Donlan 2007). The levy or trust would then fund offsets that could be one of a variety of interventions, including predator control or other conservation programs at nesting beaches (Engeman et al. 2005; Engeman et al. 2002).

For some seabirds and sea turtles offsets will not be a viable option. But for other species, a management framework that includes offsets will likely be a fruitful approach that would result in net conservation gains (Wilcox and Donlan 2007). However, those potential gains come with substantial challenges.

\section{Embracing the challenges}

The challenge to making biodiversity offsets efficacious for seabird and sea turtle conservation center on a well-designed auditing program and grappling with uncertainty. The benefits to a seabird species from an invasive rat eradication campaign on a breeding island must be quantitatively linked to the impact of the same seabird species by a fishing organization. Ecologists and economists together will have to devise a robust ecological accounting scheme that captures the cost-effectiveness of interventions, life history equivalences, demographic and environmental stochasticity, and discount rates-with the end result being offset ratios. This will be particularly challenging for sea turtles due to large differences in reproductive equivalencies between life stages, often compounded with high uncertainty for estimates. Offset opportunities will have to be carefully scoped, and will be limiting or absent for some species and populations. Potential multiple species effects will also have to be addressed on a case-by-case basis (Wilcox and Donlan 2007). Offsets will have to be undertaken with strict protocols for reporting and performance standards (ten Kate et al. 2004), and third-parties will be needed for certification of both buyers and sellers of the offsets. Such certification 
programs, however, would bring the added benefit of increased accountability and transparency for both resources users and conservation practitioners. Conservationists and government agencies will need to engage in open dialogues with the fishing sector.

There is a growing consensus that traditional institutions are not sufficiently safeguarding the biodiversity and ecosystems humanity relies on, and that 'desperate times deserve innovative measures' (Richard 2002). Those who restore islands by eradicating invasive mammals could lead the way by engaging in a dialogue with the fisheries sector about offsetting the bycatch impacts to seabirds and sea turtles, resulting in unprecedented conservation gains and new cross-sector alliances. Given the demonstrable high conservation impact and return on investment of invasive mammal eradications, anything less seems a disservice to nature and society.

Acknowledgements This work was conducted as a part of the 'Exploring compensatory mitigation and markets as mechanisms for resolving fisheries bycatch: biodiversity conservation conflicts' Working Group supported by the National Center for Ecological Analysis and Synthesis, a Center funded by NSF (Grant \#DEB-0553768), the University of California, Santa Barbara, and the State of California. CJD thanks the Robert and Patricia Foundation for their support.

\section{References}

Aguirre-Muñoz A, Croll DA, Donlan CJ, Henry RW III, Hermosillo MA, Howald GR, Keitt BS, Luna-Mendoza L, Rodríguez-Malagón M, Salas-Flores LM, SamaniegoHerrera A, Sanchez-Pacheco JA, Sheppard J, Tershy BR, Toro-Benito J, Wolf S, Wood B (2007) High-impact conservation action: invasive mammal eradication from the islands of western Mexico. Ambio 36: in press

Alverson DL, Freeberg MH, Murawski SA, Popoe JG (1994) A global assessment of fisheries bycatch and discards. Fisheries technical paper No. 339. Food and Agriculture Organization, Rome, Italy

Anonymous (2006) Federal agency cuts off fishing for isle swordfish. Star Bulletin, Honolulu, Hawaii

Barnes P (2006) Capitalism 3.0: A guide to reclaiming the commons. Berrett-Koehler Publishers, San Francisco

Botsford LW, Castilla JC, Peterson CH (1997) The management of fisheries and marine ecosystems. Science 277:509-515

Buckelew S (2007) The impacts of biological traits and anthropogenic threats on seabird extinction risk. M. A. Thesis, University of California, Santa Cruz

Burbidge AA (2004) Montebello renewal: western shield review-February 2003. Conservation Science Western Australia 5:194-201

Campbell K, Donlan CJ (2005) Feral goat eradications on islands. Conserv Biol 19:1362-1374
Caut S, Angulo E, Courchamp F (in press) Dietary shift on an invasive predator: rats, seabirds and sea turtles. J Appl Ecol

CCAMLR (2003) Scientific Committee for the Conservation of Antarctic Marine Living Resources. Report of the twentysecond meeting of the scientific committee. 27-31 October 2003, Hobart

Chambers S (2000) Markets react to a string of closures, court rulings, and campaigns. Pac Fishing 2000:1-2

Christensen J (2006) Unlikely partners create plan to save ocean habitat along with fishing. The New York Times, New York, 3 pp

Cox A (2000) Cost recovery in fisheries management. Proceedings of the international institute of fisheries economics and trade, Oregon State University, Corvalis, Oregon, 1-14 July 2000:1-15

Croll DA, Maron JL, Estes JA, Danner EM, Byrd GV (2005) Introduced predators transform subarctic islands from grassland to tundra. Science 307:1959-1961

Crowder LB, Osherenko G, Young OR, Airame S, Norse EA, Baton N, Day JC, Douvere F, Elhler CN, Halpern BS, Langdon SJ, McLeod KL, Ogden JC, Peach RE, Rosenberg AA, Wilson JA (2006) Resolving mismatches in U.S. ocean governence. Science 313

Donlan CJ, Tershy BR, Croll DA (2002) Islands and introduced herbivores: conservation action as ecosystem experimentation. J Appl Ecol 39:235-246

Donlan CJ, Tershy BR, Campbell K, Cruz F (2003) Research for requiems: the need for more collaborative action in invasive species management and conservation. Conserv Biol 17:1850-1851

Donlan CJ, Wilcox C (2007) Complexities of costing eradications. Anim Conserv 10:156-158

Engeman RM, Shwiff SA, Constantin B, Stahl M, Smith HT (2002) An economic analysis of predator removal approaches for protecting marine turtle nests at Hobe sound national wildlife refuge. Ecol Econ 42:469478

Engeman RM, Martin RE, Smith HT, Woolard J, Crady CK, Shwiff SA, Constantin B, Stahl M, Griner J (2005) Dramatic reduction in predation on marine turtle nests through improved predator monitoring and management. Oryx 39:381-326

Engeman RM, Martin RE, Smith HT, Woolard J, Crady CK, Constantin B, Stahl M, Groninger NP (2006) Impact of predation of sea turtle nests when predator control was removed from midway through the nesting season. Wildl Res 33:187-192

FAO (2004) State of the world fisheries and aquaculture, 2004. FAO, Rome, 153 pp

Ferraro PJ, Pattanayak SH (2006) Money for nothing? A call for empirical evaluation of biodiversity conservation investments. PLoS Biol 4:e105

Fukami T, Wardle DA, Bellingham PJ, Mulder CPH, Towns DR, Yeates GW, Bonner KI, Durrett MS, Grant-Hoffman MN, Williamson WM (2006) Above- and below-ground impacts of introduced predators in seabird-dominated island ecosystems. Ecol Lett 9:1299-1307

Gilman E, Brothers N, Kobayashi DR (2005) Principles and approaches to abate seabird by-catch in longline fisheries. Fish Fisheries 6:35-49 
Gilman E, Zollett E, Beverly S, Nakano H, Davis K, Shiode D, Dalzell P, Kinan I (2006) Reducing sea turtle by-catch in pelagic longline fisheries. Fish Fisheries 7:2-23

Gilman E, Kobayashi D, Swenarton T, Dalzell P, Kinan I, Brothers N (2007) Reducing sea turtle interactions in the Hawaii-based longline swordfish fishery. Biol Conserv 139:19-28

Hall M, Alverson DL, Metuzals KI (2000) By-catch: problems and solutions. Mar Pollut Bull 41:2-4-219

Hodge RA (2004) Mining's seven questions to sustainability: from mitigating impacts to encouraging contribution. Episodes 27:177-184

Howald G, Donlan CJ, Galván JP, Russell J, Parkes J, Samaniego A, Wang Y, Veitch D, Genovesi P, Pascal M, Saunders A, Tershy B (2007) Invasive rodent eradication on islands. Conserv Biol 21:1258-1268

Igual JM, Forero MG, Gomez T, Orueta JF, Oro D (2006) Rat control and breeding performance in Cory's shearwater (Calonectris diomedea): effects of poisoning effort and habitat features. Anim Conserv 9:59-65

Jacquet JL, Pauly D (2007) The rise of seafood awareness campaigns in an era of collapsing fisheries. Mar Policy 31:308-313

Jones HP, Tershy BR, Zavaleta ES, Croll DA, Keitt BS, Finklestein ME, Howald GR (in press) Global review of the effects of invasive rats on seabirds. Conserv Biol

Keitt BS, Tershy BR (2003) Cat eradication significantly decreases shearwater mortality. Anim Conserv 6:307-308

Kilgannon C (2007) Fishing fades where al that glitters is sea. The New York Times, p A1

Koch V, Nichols WJ, Peckham H, de la Toba V (2005) Estimates of sea turtle mortality from poaching and bycatch in Bahia Magdalena, Baja California Sur, Mexico. Biol Conserv 128:327-334

Lavoie C, Donlan CJ, Campbell K, Cruz F, Carrion GV (2007) Geographic tools for eradication programs of insular nonnative mammals. Biol Invasions 9:139-148

Lewison RL, Crowder LB, Read AJ, Freeman SA (2004) Understanding impacts of fisheries bycatch on marine megafauna. Trends Ecol Evol 19:598-604

Mast R (2005) SWoT report: the state of the world's sea turtles, vol I. State of the World's Sea Turtles, Washington DC

McClelland P, Tyree P (2002) Eradication: the clearance of Campbell island. N Z Geogr 58:86-94

Naidoo R, Blamford A, Ferraro PJ, Polasky S, Ricketts TH, Rouget M (2006) Integrating economic costs into conservation planning. Trends Ecol Evol 21:681-687

NMFS (2007) Fisheries of the United States 2005. National Oceanic and Atmostpheric Administrations, Silver Spring, Maryland

Nogales M, Martín A, Tershy BR, Donlan CJ, Veitch D, Puerta N, Wood B, Alonso J (2004) A review of feral cat eradication on islands. Conserv Biol 18:310-319

OECD (2003) The costs of managing fisheries. Organisation for Economic Co-operation and Development, Paris
Parkes J, Statham M, Edwards G (2005) Proceedings of the 13th Australasian vertebrate pest conference. Landcare Research, Wellington

Pullin AS, Knight TM (2001) Effectiveness in conservation practice: pointers from medicine and public health. Conserv Biol 15:50-54

Richard J (2002) Global issues networks: desperate times deserve innovative measures. Wash Q 26:17-33

Roheim CA (2003) Early indications of market impacts from the marine stewardship council's ecolabeling of seafood. Mar Resour Econ 18:95-104

Sarmiento C (2006) Transfer function estimation of trade leakages generated by court rulings in the Hawai'i longline fishery. Appl Econ 38:183-190

Simberloff D (2001) Eradication of island invasives: practical actions and results achieved. Trends Ecol Evol 16:273-274

Slootweg R, Kolhoff A, Verheem R, Höft R (2006) Biodiversity in EIA and SEA. Background document to CBD Decision VII/28: voluntary guidelines to biodiversityinclusive impact assessment. Commission for Environmental Assessment, Netherlands

Small CJ (2005) Regional fisheries management organisations: their duties and performance in reducing bycatch of albatross and other species. Birdlife International, Cambridge

ten Kate K, Bishop J, Bayon R (2004) Biodiversity offsets: views, experience, and the business case. IUCN, Gland Switzerland and Cambridge, UK, and Insight Investment, London, UK

Thomas BW, Taylor RH (2002) A history of ground-based rodent eradication techniques developed in New Zealand, 1959-1993. In: Veitch CR, Clout MN (eds) Turning the tide: the eradication of invasive species. IUCN SSC Invasive Species Specialist Group, Gland, pp 301-310

Towns DR, Atkinson IAE, Daugherty CH (2006) Have the harmful effects of introduced rats on islands been exaggerated? Biol Invasions 8:863-891

Towns DR, Broome KG (2003) From small Maria to massive Campbell: forty years of rat eradications from New Zealand islands. N Z J Zool 30:377-398

Veitch CR, Clout MN (2002) Turning the tide: the eradication of invasive species. World Conservation Union, Gland, Switzerland

Wanless RM, Angel A, Cuthbert RJ, Hilton GM, Ryan PG (2007) Can predation by invasive mice drive seabird extinctions. Biol Lett 3:241-244

Whitworth DL, Carter HR, Young RJ, Koepke JS, Gress F, Fangman S (2005) Initial recovery of Xantus's murrelets following rat eradication on Anacapa Island, California. Mar Ornithol 33:131-137

Wilcox C, Donlan CJ (2007) Compensatory mitigation as a solution to fisheries bycatch-biodiversity conservation conflicts. Front Ecol Environ 5:325-331

Wright A, de Joux V (2003) Getting results: case studies of innovation in the public service. Amherst Group Ltd 